\title{
ANALISIS TEORI PERKEMBANGAN KOGNITIF PIAGET PADA TAHAP ANAK USIA OPERASIONAL KONKRET 7-12 TAHUN DALAM PEMBELAJARAN MATEMATIKA
}

\author{
Ridho Agung Juwantara \\ Prodi Pendidikan Guru Madrasah Ibtidaiyah \\ Pascasarjana Universitas Islam Negeri Sunan Kalijaga \\ Jl. Marsda Adisucipto Yogyakarta, Indonesia \\ Email: ridhoaj57@gmail.com \\ Website: https://jurnal.uin-antasari.ac.id/index.php/adzka \\ Received: Juni 2019; Accepted: Juni 2019; Published: Juni 2019
}

\begin{abstract}
The aim of research is to examine more about the theory developed by Jean Piaget on mathematics learning according to the level of thinking of children at the stage of concrete operational age (7-12 years). The tool used in this study consisted of researchers as the main instrument. The data sources used in this study are books, journals, articles, and other scientific works. Data collection techniques in this study are documentation and interviews. Data analysis using content analysis. The results of this study indicate that children's cognitive development at the stage of concrete operational age (7-12 years) in mathematics learning varies almost at each stage of his age. In addition to the level of understanding of different students, the model and method and handling used are also very varied depending on the age phase. The results of this study can be the basis of the teacher in teaching so that learning becomes more effective, efficient, and on target. Moreover, it can encourage the achievement of national education goals.
\end{abstract}

Key Words: Piaget's cognitive development theory; concrete operational age; mathematics learning.

\begin{abstract}
ABSTRAK
Tujuan dari penelitian ini adalah untuk mengkaji lebih jauh tentang teori yang dikembangkan oleh Jean Piaget terhadap pembelajaran matematika sesuai tingkat berfikir anak pada tahap usia operaional konkret (7-12 tahun). Alat yang digunakan dalam penelitian ini terdiri dari peneliti sebagai instrumen utama. Sumber data yang digunakan dalam penelitian ini yaitu buku, jurnal, artikel, dan karya ilmiah lainnya. Teknik pengumpulan data pada penelitian ini adalah dokumentasi dan wawancara. Analisis data menggunakan content analysis. Hasil penelitian ini menunjukkan bahwa perkembangan kognitif anak pada tahap usia operasional konkret (7-12 tahun) dalam pembelajaran matematika ini berbeda-beda hampir pada setiap tahap usianya. Selain tingkat pemahaman siswa yang berbeda-beda, model dan metode serta penanganan yang digunakan juga sangat bervariatif tergantung dengan fase usianya. Hasil penelitian ini dapat menjadi landasan guru dalam mengajar sehingga pembelajaran menjadi lebih efektif, efisien, dan tepat sasaran. Terlebih dapat mendorong tercapainya tujuan pendidikan nasional.
\end{abstract}

Kata Kunci : teori perkembangan kognitif Piaget; usia operasional konkret; pembelajaran matematika 


\section{PENDAHULUAN}

Pendidikan merupakan suatu usaha yang bersifat membimbing, yang dilakukan secara sadar oleh pendidik (termasuk orang tua) terhadap peserta didik dengan tujuan untuk mengembangkan potensi peserta didik agar terbentuk kepribadian yang sempurna (insan kamil) (Marimba, 1980: 19). Aspek kognitif menjadi hal utama sebab keberhasilan dalam mengembangkan aspek kognitif dapat menentukan keberhasilan dalam aspek-aspek lainnya.

Segala hal yang ada disekitar seseorang, sesungguhnya terdapat suatu hal yang sangat bermanfaat bagi manusia jika manusia mampu menggunakan akalnya (kognitif) untuk memikirkan hal tersebut. Oleh sebab itu ketika anak sudah mampu menggunakan konsep berfikirnya maka tugas pendidikan untuk mengembangkannya. Tanpa ranah kognitif, sulit dibayangkan seorang anak mampu berfikir. Selanjutnya, tanpa kemampuan berfikir sangat mustahil seorang anak akan mampu memahami, meyakini dan mengaplikasikan hal-hal yang ia tangkap dari sekitarnya baik berupa materi pelajaran, pesan-pesan moral dari lingkungan keluarga maupun teman sebaya.

Para peneliti dalam bidang perkembangan otak menemukan bahwa perkembangan kognitif berkaitan erat dengan perkembangan dan fungsi otak. Salah satu tokoh yang merumuskan teori perkembangan kognitif yaitu Jean Piaget. Jean Piaget merupakan tokoh yang berpaham kognitif, namun dalam perkembangannya, teorinya banyak menjadi dasar teori pendidikan kontruktivisme yang berperan besar dalam pengembangan ilmu pendidikan di dunia.

Jean Piaget telah meneliti mengenai tahap-tahap pribadi serta perubahan usia yang mempengaruhi kemampuan belajar individu. Jean Piaget adalah seorang psikolog yang menyelidiki tentang pertumbuhan struktur yang memungkinkan individu mengalami penyesuaian diri dengan lingkungannya serta meneliti perkembangan intelektual atau kognisi atas dasar bahwa struktur intelektual terbentuk didalam individu akibat interaksinya dengan lingkungan (Soemanto, 1998: 130).

Menurut Piaget, Tingkah laku seseorang senantiasa didasarkan pada kognisi, yakni suatu tindakan untuk mengenal atau memikirkan kondisi dimana suatu perilaku itu terjadi. Jadi secara tidak langsung pribadi anak akan terbentuk melalui proses belajar yang melibatkan proses berfikir yang sangat kompleks dan merupakan peristiwa mental yang nantinya mendorong terjadinya sikap maupun perilaku.

Pandangan dunia anak tahap operasional konkret (7-12 tahun) berbeda dengan pandangan orang tua atau yang lebih dewasa, jadi pendidik harus mampu mendorong anak untuk membentuk konsep yang tepat khususnya dalam pembelajaran matematika. Sebab, Praktek pembelajaran matematika di Indonesia sangat dipengaruhi oleh teori belajar kognitif. Berbagai upaya telah dirintis untuk memperbaiki praktek pembelajaran matematika dengan berpegang pada aliran tersebut. Aliran teori belajar kognitif diyakini sebagai suatu pembaharuan atau inovasi belajar yang diharapkan dapat memperbaiki kualitas pendidikan matematika di Indonesia. Dengan demikian, sangat perlu dikaji lebih jauh tentang teori yang dikembangkan oleh Jean Piaget tersebut. Sebab hal ini sangat membantu pendidik dalam mengemas materi ataupun metode yang dikemas sesuai tingkat berfikir anak. Terutama dalam hal ini pada anak usia sekolah dasar di Madrasah Ibtidaiyah Qurrotta A'yun Yogyakarta yang rata-rata berada di tahap usia operasinal konkret (7-12 tahun).

\section{a. Teori Perkembangan Kognitif Jean Piaget}

Istilah perkembangan merujuk pada bagaimana orang tumbuh, menyesuaikan diri, dan berubah sepanjang perjalanan hidupnya melalui perkembangan fisik, perkembangan kepribadian, perkembangan sosioemosi, perkembangan kognisi (pemikiran), dan perkembangan bahasa (Rita L., 2010: 9).

Istilah cognitive berasal dari kata cognition yang padanannya knowing, berarti mengetahui. Dalam arti yang luas cognitive (kognisi) ialah perolehan, penataan, dan 
penggunaan pengetahuan. Dalam perkembangan selanjutnya, istilah kognitif menjadi popular sebagai salah satu domain atau wilayah / ranah psikologis manusia yang meliputi setiap perilaku mental yang berhubungan dengan pemahaman, pertimbangan, pengolahan informasi, pemecahan masalah, kesengajaan, dan keyakinan. Ranah kejiwaaan yang berpusat di otak ini juga berhubungan dengan konasi (kehendak) dan afeksi (perasaan) yang bertalian dengan ranah rasa (Muhibbin, 2012: 2).

Teori perkembangan kognitif Piaget adalah salah satu teori yang menjelasakan bagaimana anak beradaptasi dan menginterpretasikan dengan objek dan kejadian-kejadian sekitarnya. Bagaimana anak mempelajari ciri-ciri dan fungsi dari objek-objek seperti mainan, perabot, dan makanan serta objek-objek sosial seperti diri, orangtua, dan teman. Bagaimana cara anak mengelompokkan objek-objek untuk mengetahui persamaan-persamaan dan perbedaan-perbedaannya, untuk memahami penyebab terjadinya perubahan dalam objekobjek dan perisiwa-peristiwa dan untuk membentuk perkiraan tentang objek-objek dan peristiwa tersebut (“Teori Perkembangan Kognitif Jean Piaget," n.d.).

Dalam pemikirannya tentang perkembangan kognitif, Piaget menjelaskan mengenai mekanisme dan proses perkembangan kognitif manusia dari bayi, masa kanak-kanak hingga menjadi manusia dewasa yang bernalar dan berpikir. Ia menyimpulkan bahwa organisme bukanlah agen yang pasif dalam perkembangan genetik. Perkembangan genetik secara aktif terjadi karena adanya adaptasi terhadap lingkungan dan interaksinya dengan lingkungannya. Untuk memahami teori perkembangan Piaget, ada beberapa konsep yang perlu dipahami terlebih dahulu, yaitu sebagai berikut:

\section{Skema}

Ketika anak berusaha untuk membangun pemahaman mengenai dunia, otak berkembang menciptakan skema. Ini adalah tindakan atau representasi mental yang merorganisasikan pengetahuan. Dalam teori Piaget, skema perilaku (aktivitas fisik) ciri bayi, dan skema mental (kegiatan kognitif), berkembang di masa kanak-kanak (Santrock, 2017: 43-44). Skema bayi disusun oleh tindakan sederhana yang dapat dilakukan terhadap benda-benda seperti menggenggam, menghisap, dan melihat.

\section{Asimilasi}

Asimilasi adalah konsep Piaget tentang tergabungnya informasi baru kedalam pengetahuan yang ada (skema). Aslimilasi merupakan proses kognitif dimana seseorang mengintegrasikan persepsi, konsep atau pengalaman baru ke dalam skema atau pola yang sudah ada di dalam fikirannya. Asimilasi tidak menyebabkan perubahan skemata, tetapi memperkembangkan skema semata.

\section{Akomodasi}

Akomodasi merupakan konsep Piaget tentang pengelompokan perilaku terisolasi ke tatanan sistem kognitif yang lebih tinggi dengan fungsi yang lebih baik. Akomodasi adalah pembentukan skema baru atau mengubah skema yang lama, hal ini terjadi karena dalam menghadapi rangsangan/pengalaman baru, seseorang tidak dapat mengasimilasikan pengalaman yang baru itu dengan skema yang telah ia miliki, ini terjadi karena pengalaman baru itu tidak cocok dengan skema yang telah ada (Surna, 2014: 58).

\section{Organisasi}

Organisasi dalam teori Piaget adalah pengelompokan perilaku dan pikiran yang terisolasi ke dalam sistemyang lebih tinggi. Menunjuk pada tendensi semua spesies untuk mengadakan sistematisasi dan mengorganisasi proses-proses mereka dalam suatu sistem yang koheren, baik secara fisis maupun psikologis. Contohnya yaitu bayi menggabungkan kemampuan melihat dan menjamah. 


\section{Ekuilibrasi}

Ekuilibrium merupakan mekanisme untuk menjelaskan bagaimana anak-anak berpindah dari satu tahap pemikiran ke tahap berikutnya. Pergeseran ini terjadi karena anak mengalami konflik kognitif (disekuilibrium), dalam mencoba untuk memahami dunia.

Dalam teori perkembangannya, Piaget menegaskan bahwa belajar akan lebih berhasil apabila disesuaikan dengan tahap perkembangan kognitif peserta didik. Dengan pemahaman tersebut maka sangat penting untuk memberikan kesempatan bagi peserta didik untuk melakukan eksperimen bersama kelompok teman-temannya dan dibantu oleh pertanyaan tilikan dari pendidik. Pendidik memainkan peran penting dalam proses tersebut dengan memberikan rangsangan kepada peserta didik agar sudi berinteraksi dengan lingkungan secara aktif, dan mencari serta menemukan berbagai hal dari lingkungan.

\section{b. Perkembangan Kognitif Anak Usia Operasional Konkret (7-12 Tahun)}

Perkembangan kognitif merupakan pertumbuhan berfikir logis dari masa bayi hingga dewasa, menurut Piaget perkembangan yang berlangsung melalui empat tahap, yaitu:

Tabel 1. Tahapan Perkembangan Usia

\begin{tabular}{|c|l|c|}
\hline No & \multicolumn{1}{|c|}{ Tahap Perkembangan } & Usia \\
\hline 1 & Tahap sensori-motor & $0-1,5$ tahun \\
\hline 2 & Tahap pra-operasional & $1,5-6$ tahun \\
\hline 3 & Tahap operasional konkrit & $6-12$ tahun \\
\hline 4 & Tahap operasional formal & 12 tahun ke atas \\
\hline
\end{tabular}

Piaget percaya, bahwa kita semua melalui keempat tahap tersebut, meskipun mungkin setiap tahap dilalui dalam usia berbeda. Setiap tahap dimasuki ketika otak kita sudah cukup matang untuk memungkinkan logika jenis baru atau operasi (Jarvis, 2011: 148). Semua manusia melalui setiap tingkat, tetapi dengan kecepatan yang berbeda, jadi mungkin saja seorang anak yang berusia 6 tahun berada pada tingkat operasional konkrit, sedangkan ada seorang anak yang berusia 8 tahun masih pada tingkat pra-operasional dalam cara berfikir. Namun urutan perkembangan intelektual sama untuk semua anak, struktur untuk tingkat sebelumnya terintegrasi dan termasuk sebagai bagian dari tingkat-tingkat berikutnya (Dahar, 2011: 137).

Pada tahap Operasional Konkret (7-12 tahun), anak sudah cukup matang untuk menggunakan pemikiran logika atau operasi, tetapi hanya untuk objek fisik yang ada saat ini. Dalam tahap ini, anak telah hilang kecenderungan terhadap animism dan articialisme. Egosentrisnya berkurang dan kemampuannya dalam tugas-tugas konservasi menjadi lebih baik. Namun, tanpa objek fisik di hadapan mereka, anak-anak pada tahap operasional kongkrit masih mengalami kesulitan besar dalam menyelesaikan tugas-tugas logika.

Pada tahap ini anak mengembangkan kemampuan untuk mempertahankan (konservasi), kemampuan mengelompokkan secara memadai, melakukan pengurutan (mengurutkan dari yang terkecil sampai paling besar dan sebaliknya), dan menangani konsep angka. Tetapi, selama tahap ini proses pemikiran diarahkan pada kejadian riil yang diamati oleh anak. Anak dapat melakukan operasi problem yang agak kompleks selama problem itu konkret dan tidak abstrak (Hergenhahn \& Olson, 2015).

\section{c. Prinsip-Prinsip Pembelajaran kognitif}

Dalam memahami konsep pembelajaran kognitif, ada tiga prinsip utama pembelajaran yang dikemukakan Piaget, yaitu sebagai berikut:

\section{Belajar Aktif}

Proses pembelajaran adalah proses aktif, sebab pengetahuan terbentuk dari dalam subyek belajar. Untuk membantu perkembangan kognitif anak, kepadanya perlu diciptakan suatu kondisi belajar yang memungkinkan anak belajar sendiri, misalnya melakukan percobaan 
sendiri, memanipulasi symbol-simbol, mengajukan pertanyaan dan mencari jawaban sendiri, atau membandingkan penemuan sendiri dengan penemuan temannya.

\section{Belajar Lewat Interaksi Sosial}

Dalam belajar, perlu dicptakan suasana yang memungkinkan terjadinya interaksi di antara subyek belajar. Menurut Piaget, belajar bersama teman sebaya maupun orang yang lebih dewasa akan membantu perkembangan kognitif mereka. Sebab, tanpa kebersamaan, kognitif akan berkembang dengan sifat egosentris. Dan dengan kebersamaan, khazanah kognitif anak akan semakin beragam.

\section{Belajar Lewat Pengalaman Sendiri}

Dengan memanfaatkan pengalaman nyata, perkembangan kognitif seseorang akan lebih baik daripada hanya menggunakan bahasa untuk berkomunikasi. Berbahasa sangat penting untuk berkomunikasi. Namun, jika tidak diikuti oleh penerapan dan pengalaman maka perkembangan kognitif seseorang akan cenderung mengarah ke verbalisme (banyak menghafal) (Mashudi, 2013: 42-43).

\section{d. Implikasi Teori Jean Piaget Dalam Pembelajaran Matematika}

Matematika merupakan ilmu pengetahuan yang objek kajiannya bersifat abstrak sehingga memerlukan penalaran deduktif untuk memahaminya. Oleh karena itu, belajar matematika selalu dikaitkan dengan kesiapan kognitif. Dalam hal ini, belajar dipandang sebagai hasil pencapaian dan perkembangan dari struktur kognitif. Kesiapan anak untuk belajar matematika ditinjau dari kesiapan struktur kognitifnya, yaitu kapasitas kemampuan berpikir secara terorganisir dan terkoordinir. Struktur kognitif diperlukan untuk mengembangkan kemampuan penalaran yang dapat distimulasi melalui pengkajian matematis suatu objek. Jadi, ada hubungan timbal balik antara kesiapan struktur kognitif dengan pengembangan kemampuan penalaran dalam konteks belajar matematika.

Dalam percobaan Piaget, ternyata anak pada tahap pra-operasional konkret belum dapat mengerti soal korespondensi satu-satu dan kekekalan. Namun, pada tahap operasional konkret, anak sudah dapat mengerti soal korespondensi dan kekekalan dengan baik. Dengan perkembangan ini berarti konsep tentang bilangan bagi anak telah berkembang (Rahyubi, 2012: 132). Menurut Piaget pendekatan yang digunakan yaitu konstruktif. Pendekatan ini memungkinkan anak belajar dengan baik jika ia aktif dan mencari solusi secara mandiri. Metode pembelajarannya ialah dengan eksperimen dan berdiskusi, serta mengurangi metode ceramah dan hafalan materi.

\section{METODE PENELITIAN}

Metode penelitian yang digunakan dalam penelitian ini yaitu metode penelitian kualitatif. Metode penelitian kualitatif adalah metode penelitian yang digunakan untuk meneliti pada kondisi obyek alamiah, dimana peneliti adalah sebagai intrumen kunci (Sugiyono, 2016). Berdasarkan objek kajian, penelitian ini termasuk penelitian yang bersifat litere atau kepustakaan (library research). Library research adalah suatu peneltian yang dilakukan dengan cara mengumpulkan data, informasi, dan berbagai macam data-data lainnya yang terdapat dalam kepustakaan. Sumber data yang digunakan dalam penelitian ini yaitu buku, jurnal, artikel, dan karya ilmiah lainnya yang relevan dengan objek kajian pada penelitian ini. Pokok bahasan dalam penelitian ini yaitu teori-teori yang berkaitan dengan perkembangan kognitif anak usia dasar dan implikasinya dalam kegiatan belajar mengajar terutama mata pelajaran matematika.

Teknik pengumpulan data pada penelitian ini adalah dokumentasi dan sedikit tambahan berupa wawancara. Selanjutnya, untuk mengolah dan menganalisis data, penulis menggunakan metode content analysis yaitu sebuah analisis terhadap kandungan isi yang berfokus pada interpretasi dari teori-teori kognitif anak usia dasar.Sumber data yang digunakan dalam penelitian ini yaitu buku, jurnal, artikel, dan karya ilmiah lainnya yang 
relevan dengan objek kajian pada penelitian ini. Pokok bahasan dalam penelitian ini yaitu teori-teori yang berkaitan dengan perkembangan kognitif anak usia dasar dan implikasinya dalam kegiatan belajar mengajar. Teknik pengumpulan data pada penelitian ini adalah dokumentasi. Selanjutnya, untuk mengolah dan menganalisis data, penulis menggunakan metode content analysis yaitu sebuah analisis terhadap kandungan isi yang berfokus pada interpretasi dari teori-teori kognitif anak usia dasar.

\section{HASIL PENELITIAN DAN PEMBAHASAN}

Perkembangan kognitif akan mempengaruhi fungsi otak untuk berfikir, seperti mengetahui, memahami, menganalisis, mensintesis, bernalar, berkreatifitas dan bertindak. Perkembangan otak terbagi menjadi dua bagian, yaitu otak kiri dan otak kanan. Perkembangan otak kiri meliputi kemampuan berfikir rasional, ilmiah, logis, analitis, danberkaitan dengan kemampuan belajar membaca, berhitung dan bahasa. Perkembangan otak kanan meliputi kemampuan berfi kir holistik, non-linier, non-verbal, intuitif, imajinatif dan kreatifitas. Pada fase anak usia dasar, perkembangan kognitif anak memiliki tingkatan yang berbeda-beda dimulai dari usia 7-12 tahun ke atas. Pada fase ini, perkembangan kognitif anak berada dalam dua fase yaitu pertama fase operasional konkret adalah fase ketika usia anak antara 7 sampai 12 tahun dan kedua fase operasional formal adalah fase ketika usia anak antara 11 sampai 12 tahun ke atas. Perkembangan kognitif setiap individu berbeda-beda, ada yang cepat dan ada juga yang lambat. Perbedaan tersebut dapat terjadi karena dipengaruhi berbagai faktor, diantaranya yaitu asupan gizi. Sebuah penelitian menunjukan bahwa anak kekurangan gizi (malnutrisi) memiliki IQ dengan rata-rata nilai 22,6 poin lebih rendah dibandingkan anak berstatus gizi baik (Puspitasari, Sudargo, \& Gamayanti, 2011: 52-60). Selain itu faktor hereditas (keturunan) dan faktor lingkungan sangat berpengaruh terhadap perkembangan kognitif anak.

\section{Perkembangan Kognitif Anak Usia Tujuh sampai Dua Belas Tahun serta Implikasinya terhadap Pembelajaran Matematika}

Usia 7-12 tahun merupakan usia ketika anak sudah memasuki masa sekolah. Sebagaimana menurut teori kognitif Piaget, pemikiran anakanak usia sekolah dasar disebut pemikiran operasional konkret (concrete operational) (Desmita, 2015: 156). Makna operasional konkret yang dimaksud oleh Piaget yaitu kondisi dimana anak-anak sudah dapat memfungsikan akalnya untuk berfikir logis terhadap sesuatu yang bersifat konkret atau nyata. Pada tahapan ini, pemikiran logis menggantikan pemikiran intuitif (naluri) dengan syarat pemikiran tersebut dapat diaplikasikan menjadi contoh-contoh yang konkret atau spesifik. Akan tetapi, kekurangan dari pada fase ini adalah ketika anak dihadapkan dengan pemasalahan yang bersifat abstrak (secara verbal) tanpa adanya objek nyata, maka ia akan mengalami kesulitan bahkan tidak mampu untuk menyelesaikannya dengan baik (Santrock, 2007: 255). Akan tetapi, kekurangan dari pada fase ini adalah ketika anak dihadapkan dengan pemasalahan yang bersifat abstrak (secara verbal) tanpa adanya objek nyata, maka ia akan mengalami kesulitan bahkan tidak mampu untuk menyelesaikannya dengan baik. Penalaran anak masih terbatas, kendati dapat menalar secara logis dan memahami hubungan-hubungan kausal, mereka belum dapat melakukan penalaran hipotesis atau abstrak.

Anak hanya dapat memecahkan suatu masalah ketika objek dari masalah tersebut bersifat empirik (nyata) atau ditangkap oleh paca indra mereka, bukan yang bersifat khayal. Khususnya pada tahap operasional konkret ditandai dengan adanya sistem operasi berdasarkan segala sesuatu yang kelihatan nyata atau konkret. Anak masih memunyai kesulitan untuk menyelesaikan persoalan yang mempunyai banyak variabel. Misalnya, bila suatu benda A dikembangkan dengan cara tertentu menjadi benda B, atau dikembalikan kesemula menjadi benda A. Dalam matematika diterapkan dalam operasi penjumlahan, pengurangan, dan lainnya. 


\section{Contohnya, $5+3=8$ dan 8-3=5}

Kemampuan matematika pada usia ini sudah semakin baik, anak sudah dapat memahami jenis ukuran (berat, panjang, dan volume), tetapi belum sampai pada tahap perubahan ukuran dan sudah bisa mengenal diagram batang. Anak sudah bisa mengoperasikan perkalian dan pembagian, tetapi masih sebatas bilangan asli. Namun, ketika diberi soal yang berbentuk angka yang berbeda, biasanya anak akan mengalami kesulitan dalam menjawabnya. Misalnya, anak-anak diajarkan perkalian angka dibawah 10, ketika diberi pertanyaan dengan angka diatas 10 (dua dijit angka), tidak jarang anak mengalami kesulitan untuk menjawabnya (Hasil Wawancara dengan Guru MI Qurrotta A'yun Yogyakarta, 2019). Anak belum bisa mengoperasikan perkalian dan pembagian angka desimal dan pada skala angka yang mencapai ribuan. Pembelajaran yang berbasis alam (lingkungan sekitar) sangat relevan dengan fase ini, karena anak membutuhkan lingkungan belajar di alam yang terbuka, supaya tidak jenuh dan bosan. Selain dari pada itu, agar anak dapat memahami materi dengan lebih mudah, sebaiknya guru menghadirkan contoh nyata dan melakukan percobaan (eksperimen) terhadap materi yang dipelajari. Pada usia 7-8 tahun, anak bisa fokus mengikuti pembelajaran dengan durasi yang hanya berkisar 2-3 jam, selebihnya anak akan merasa lelah, mengantuk dan cenderung mencari aktifi tas bermain. Anak sudah bisa belajar dengan nuansa yang formal, tetapi masih membutuhkan pembelajaran yang menyenangkan, seperti pembelajaran yang berbasis permainan (game).

Pada usia 9 tahun, Kemampuan matematika anak semakin baik, anak tidak hanya mengenal jenis bangun datar, tetapi sudah bisa menghitung luas bangun datar dan sudah bisa mengenal bangun ruang. Anak juga dapat memahami proses perubahan bentuk bangun, misalnya bangun persegi dapat dibentuk menjadi dua bangun segitiga atau berbentuk jajar genjang. Anak dapat menghitung angka dalam pikiran tanpa menghitung dengan cara manual atau menulis. Misalnya, ketika ditanya tentang perkalian angka puluhan dengan satuan, anak bisa menjawab secara spontan, tetapi ketika mengalikan angka puluhan dengan puluhan bahkan ratusan, anak belum bisa menjawabnya tanpa dengan bantuan perhitungan manual. Pada fase ini, sudah bisa diterapkan sistem pembelajaran dengan diskusi kelompok.

Pada anak usia 9-10 tahun, kemampuan matematika anak juga semakin baik, anak dapat menyelesaikan soal-soal yang lebih rumit, misalnya mengoperasikan bilangan pecahan dan desimal, menghitung luas sebagian dari suatu bangun datar, menghitung volume bangun ruang dan menghitung perubahan ukuran benda, seperti kilo gram ke gram, centi meter ke meter dan lain sebagainya. Anak juga dapat mengoperasikan perkalian dan pembagian dalam memecahkan soal yang berbentuk narasi atau cerita. Pada fase ini, dalam pembelajaran, anak sudah bisa diterapkan sistem belajar Cooperatif learning yaitu sistem pembelajaran dengan cara anak belajar dan bekerja sama (kaloboratif) dalam kelompok-kelompok kecil. Disini pembelajaran sudah bisa mendorong anak dalam berkomunikasi (sharing), bertkukar ide dan gagasan dengan temannya dalam memecahkan suatu permasalahan. Anak-anak bisa diajak bernalar kritis terhadap objek-objek yang belum mereka ketahui sebelumnya.

Pada usia 11 sampai dua belas tahun keatas, daya ingat anak semakin kuat dan sudah bisa berpikir strategis serta menyusun siasat. Sebagai contoh dalam suatu penelitian menemukan bahwa dua orang anak berusia 10 dan 12 tahun yang berpengalaman bermain catur (ahli) mampu mengingat lebih banyak informasi mengenai bidak catur dibandingkan dengan orang dewasa yang bukan pemain catur (pemula) (Santrock, 2007: 193). Hasil penelitian tersebut menunjukan bahwa kompetensi kogitif anak pada usia ini sudah bisa berfi kir strategis sistematis. Kemampuan matematika anak semakin kompleks, jika sebelumnya hanya dapat menghitung luas bangun datar, pada fase ini anak sudah bisa menghitung luas, keliling dan volume bangun ruang. Anak bisa mengerjakan soal-soal yang rumit, seperti operasi akar dan mengoperasikan angka yang bernominal tinggi (ribuan dan jutaan). Pada fase ini sudah bisa diterapkan model pembelajaran yang terpusat pada siswa (student center), salah 
satunya yaitu model pembelajaran Inkuiri. Model pembelajaran Inkuiri adalah suatu pola pembelajaran dari proses pengamatan menjadi pemahaman.

\section{PENUTUP}

Dari hasil analisis dan pembahasan diatas dapat disimpulkan bahwa perkembangan kognitif anak pada usia tahap operasional konkret (7-12 tahun) dalam pembelajaran matematika ini berbeda-beda hampir pada setiap tahap usianya. Pada usia 7-8 tahun, Anak belum bisa mengoperasikan perkalian dan pembagian angka desimal dan pada skala angka yang mencapai ribuan. Pembelajaran yang berbasis alam (lingkungan sekitar) sangat relevan dengan fase ini, karena anak membutuhkan lingkungan belajar di alam yang terbuka. Selanjutnya, pada usia 9-10 anak dapat mengoperasikan perkalian dan pembagian dalam memecahkan soal yang berbentuk narasi atau cerita. Pada fase ini, dalam pembelajaran, anak sudah bisa diterapkan sistem belajar Cooperatif learning. Dan pada usia 11 sampai 12 tahun keatas, kemampuan matematika anak semakin kompleks, jika sebelumnya hanya dapat menghitung luas bangun datar, pada fase ini anak sudah bisa menghitung luas, keliling dan volume bangun ruang. Anak bisa mengerjakan soal-soal yang rumit, seperti operasi akar dan mengoperasikan angka yang bernominal tinggi (ribuan dan jutaan). Pada fase ini sudah bisa diterapkan model pembelajaran yang terpusat pada siswa (student center) seperti inkuiri.

Jadi selain tingkat pemahaman siswa yang berbeda-beda, juga model dan metode serta penanganan yang digunakan juga sangat bervariatif tergantung dengan fase usianya. Ini dapat menjadi landasan guru dalam mengajar sehingga pembelajaran menjadi lebih efektif, efisien, dan tepat sasaran. Terlebih dapat mendorong tercapainya tujuan pendidikan nasional..

\section{DAFTAR PUSTAKA}

Dahar, R. Wi. (2011). Teori Belajar dan Pembelajaran, Cet. V. Jakarta: Erlangga.

Desmita, D. (2015). Psikologi Perkembangan, Cet. Ke-9. Bandung: PT. Remaja Rosdakarya.

Hasil Wawancara dengan Guru MI Qurrotta A'yun Yogyakarta. (2019). Dilakukan pada 4 Mei 2019

Hergenhahn, B. R., \& Olson, H. (2015). Theories of Learning. Jakarta: Kencana.

Jarvis, M. (2011). Teori-Teori Psikologi, Cet. X. Bandung: Nusa Media.

Marimba, A. D. (1980). Pengantar Filsafat Pendidikan Islam. Bandung: PT. Al Maaarif.

Mashudi, F. (2013). Psikologi Konseling Buu Panduan Lengkap dan Praktis Menerapkan Psikologi Konseling. Yogyakarta: Ircisod.

Muhibbin, S. (2012). Psikologi Belajar. Jakarta: Rajawali Pers.

Puspitasari, F. D., Sudargo, T., \& Gamayanti, I. L. (2011). Hubungan Antara Status Gizi dan Faktor Sosio Demografi dengan Kemampuan Kognitif Anak Sekolah Dasar Di Daerah Endemis Gaki. Jurnal Gizi Indonesia, 34(1), 52-60.

Rahyubi, H. (2012). Teori-Teori Belajar Dan Aplikasi Pembelajaran Motorik. Bandung: Nusa Media.

Rita L., A. (2010). Pengantar Psikologi Jilid 1. Jakarta: Erlangga.

Santrock, J. W. (2007). Perkembangan Anak, terj. Mila Rachmawati dan Anna Kuswanti. Jakarta: Erlangga.

Santrock, J. W. (2017). Educational Pshykology. Jakarta: Salemba Humanika.

Soemanto, W. (1998). Psikologi Pendidikan, Landasan Kerja Pemimpin Pendidikan. Jakarta: Rineka Cipta.

Sugiyono, S. (2016). Memahami Penelitian Kualitatif, Cet. Ke-12. Bandung: Alfabeta.

Surna, I. N. (2014). Psikologi Pendidikan. Jakarta: Erlangga.

Teori Perkembangan Kognitif Jean Piaget. (n.d.). Retrieved from http://prezi.com/uepcgwoue5_m/teori-perkembangan-kognitif-jean-piaget. 15 Mei 2019. 